Milanka Marković1 ${ }^{\text {, Snežana Knežević }}{ }^{\text {, Andrijana Brown }}{ }^{3}$, Veljko Dmitrović ${ }^{2}$

${ }^{1}$ Belgrade Business School, Belgrade

2 University of Belgrade, Faculty of Organizational Sciences, Serbia

${ }^{3}$ Liberty Tax Inc., Leesburg, Virginia, USA

\title{
Measuring the Productivity of Serbian Banks Using Malmquist Index
}

UDC: 005.336.1:336.71(497.11)

005.31

DOI: 10.7595/management.fon.2015.0022

This paper evaluates the scale of productivity change of the Bank of Serbia over the period 2007- 2010. In this research the emphasis is put on measuring the productivity based on information from the financial statements using Data Envelopment Analysis (DEA) method and Malmquist index to estimate the individual bank efficiency and productivity changes within this period. The Malmquist productivity indices have been decomposed into technical changes of efficiency index and index of technology changes. DEA is an increasingly popular management tool. It is widely known what represents an input and what is output in banking operations, but for an adequate analysis of the efficiency or the productivity of banks it is essential to choose the right combination of inputs and outputs of the bank. In relevant academic literature various combinations of inputs and outputs could be seen for measuring the efficiency and productivity of banks. This paper shows the productivity decrease of the banking sector.

Keywords: efficiency, productivity, banks, financial information, DEA method, Malmquist Index

\section{Introduction}

The time series are sequences of data that show the size or level of occurrences over time. Time is not just a period of observation, but also a factor that contributed to the variation. i.e., changes.

Measuring productivity over time has two aspects, related to the level and trend of productivity. The one that refers to the level has three types of productivity coefficients: partial productivity, total factor productivity and total productivity.

According to the classical economic theory, efficiency is measured as the ratio of one output and one input (Knežević et al., 2012). In practice, business entities have many diverse inputs and outputs. The problem arises if a common expression for them cannot be found.

To analyze productivity, efficiency and profitability means to analyze the three forms of business efficiency, namely:

- technical efficiency or productivity, which represents the ratio between the produced quantities or units of products or services and production factors (employees, working hours, resources);

- economic efficiency or cost-effectiveness, which represents the ratio of revenues/expenses;

- financial efficiency or profitability, which represents the ratio of profit/assets.

Another aspect of the productivity trend is defined by looking at changes over time. Productivity growth is one of the main sources of economic growth. In recent years, measurement and analysis of changes in productivity have become of interest to many researchers concerning benchmark firms.

Generally speaking, the principle of efficiency is achieved if there are the highest possible economic effects of output values (output) with minimum economic investment (input). 
In the times of economic crises, each bank must observe competitors in order to improve efficiency of operations. The index follows up the relative position of the bank on the frontier which consists of the best banks.

Andries (2011) points out that the efficiency of the banking system is the issue of interest of both the academic world and policy-makers in the banking system in the entire world. In their paper Afsharian \& Ahn (2015) proposed a new method for preparing a global framework of the Malmquist index which applies the minimum extrapolation principle on the aggregation of the experienced contemporaneous technologies, and it is illustrated on a real example from banking. Further, the paper by Kao \& Liu (2014) has calculated the global Malmquist productivity index (MPI) as a measure of the change in performance. As perceived by the same authors, the global financial crisis was the reason for the increased interest of the governments for the financial condition of the banks. In his study Liu (2010) applied the Malmquist productivity index to measure changes in efficiency and productivity of the 25 commercial banks in Taiwan, which is calculated from efficiency scores based on the DEA linear programming technique. Bassem (2014) presents his research which relates to the measurement of productivity change in Middle East and North Africa MFIs during which he applies the Malmquist productivity index and a balanced panel dataset of 198 observations from 33 MFIs. Using the data for the period 1998-2007 in their research, Sufian \& Habibullah (2014) also use the Malmquist Productivity Index method, and calculate the total factor of productivity of the banking sector in Malaysia. In a study of Zhang Qu, Xu and Wang (2012) productivity of 150 Chinese banks was examined for the period 1999-2008. (M-index) and the relationship between market development and profit efficiency of banks and in the conclusion it is pointed out that for the observed Chinese banks, productivity growth can mainly be attributed to improvements in technical efficiency and technical change.

\section{Problem definition}

In the remainder of this paper the application of M1 and M2 models is going to be presented in the banking sector of Serbia. Four distance functions $\mathrm{D}($.) are required to estimate the Malmquist productivity index, and also they are estimated by using CRS input - oriented to score efficiency.

Malmquist indexes of banks have been calculated using Excel Solver to set up the abovementioned conditions for models M1 and M2.

\subsection{Financial data}

For the application of the model we used data on assets, the number of employees and equity as inputs, and the total revenue and EBT as outputs. Due to the unavailability of data only four years have been observed, and those are 2007, 2008, 2009 and 2010 for the entire Serbian banking sector. This is a preliminary model of authors' research.

\subsection{Malmquist Index}

Efficiency simply means successfullness and shows the degree of effectiveness of the companies that have specific inputs (deposits, borrowings, engaged funds, property, etc.) for the production or services to obtain the output values such as revenues, profit, etc.

The standard way of measuring productivity is the output-input ratio. Measurement of productivity can be done in two ways, taking into account the level and trend of productivity. The productivity ratio represents a level at a given moment, expressed as relation between a produced output and a combination of utilized inputs. For the examination of change in dynamics of productivity over time indices have been used, while the analysis of variations of productivity in the function of time comes down to the research of development tendencies models.

The ratio analysis provides a relatively insignificant amount of information when considering the effects of economies of scale and evaluating overall measures of a bank's performance. The ratios are used to identify trends over time for one bank or to compare two or more banks at one point in time (see more - Knežević et al., 2011). As an alternative to traditional bank tools for the bank management of bank efficiency, the frontier 
DEA analysis was used that enables management to objectively identify the best practices in the dynamic environment in which banks operate (see more - Yang, 2009). DEA provides a comprehensive analysis of the relative efficiencies for defined inputs and outputs, i.e., input and output parameters (Banker et al., 1984).

The formula for the application of DEA efficiency is the following:

$D E A$ Efficiency $=\frac{\text { weghted sum of outputs }}{\text { weghted sum of inputs }}, 0 \leq D E A$ Efficiency $\leq 1$

The DEA method estimates every DMU as a relatively efficient or relatively inefficient. DEA estimates the efficiency of a DMU by maximizing the ratio of a weighted sum of outputs over a weighted sum of inputs. This ratio is equal to 1 and indicates an efficient unit. To solve the problem, firstly, this ratio is transformed into a linear form and then the dual case is measured with simplex method of linear programming. The DEA is a specifically defined procedure for measuring the efficiency of complex units of a business system with a variety of inputs and outputs (see more details - Yang, 2009). A Decision Making Unit (DMU) is the standard name for the business units that are included in the efficiency analysis of units on the basis of selected input and output values. For the analysis of the efficiency dynamics of production technology and productivity of DMU over time the so called Windows DEA analysis has been developed, as well as Malmquist DEA index analysis. Each model of analysis has its own assumptions that must be satisfied for the results to be valid and usable.

Indices are special relative numbers that have a very wide application in practice. Indices are used primarily for testing dynamic phenomena, i.e., their changes in time. If the time series of absolute data change indices, it is possible to analyze the development of the phenomenon. Therefore, they are often referred to as indices of dynamics or developments. They are calculated as the ratio of the different levels of one or more occurrences of the same name at different times or in different places. Indices are expressed as a percentage, i.e., the ratio is multiplied by 100 . Indices are different from the coefficients.

Malmquist indices which became commonly known are based on the DEA method (Fare et al., 1994a, 1994b). In 1953 Malmquist was the first to propose quantitative indices for measuring the success of using inputs for the production of outputs (see more - Malmquist, 1953). Comparisons can be made between the two companies $A$ and $B$.

Suppose that production functions for the two companies $A$ and $B$ are known: $y A A=f A(K A, L A)$ and $y B B=$ $f B(K B, L B)$.

Now inputs of $A$ should be replaced by inputs of $B$ and vice versa, and then we get two new values: $y A B=$ $f A(K B, L B)$ and $y B A=f B(K A, L A)$.

Malmquist index $A$ compared to $B$ is a geometric mean $y A A / y A B$ and $y B A / y B B$. If it is higher than 1 , then the production technology in company $A$ is better than in company $B$.

In the same way one can get Malmquist index if, instead of economies $A$ and $B$, it considers two time intervals $t$ and $t+1$.

Measuring the Malmquist productivity index is an important method which has numerous applications. The Malmquist productivity index based on the DEA method is calculated as a geometric mean of the two main Malmquist productivity indices which are defined as functions of distance $\mathrm{D}($.$) introduced by Caves et al.$ (1982) and Fare et al. (1992), by combining the Malmquist index with Farrell's (1957) idea of measuring efficiency; Caves's idea of productivity measurement defined Malmquist indices directly from the input and output data using the DEA method.

The distance function for period $t$ and $t+1$ is defined in the following way (Shephard, 1970; Färe, 1988; Färe et. al., 1994b; Farrell's, 1957):

$D^{t}\left(x^{t}, y^{t}\right)=\min \left\{Z: x^{t} / Z \in P^{t}\left(x^{t}\right)\right\}$.

If $Z$ is a minimum then $y^{t} / Z$ is a maximum and we can say that the distance function measures the maximum possible output that can be produced with a given input. This is a measure of technical efficiency. In a similar way one can define the 
distance function for the period $t+1$, i.e. $D^{t+1}\left(x^{t+1}, y^{t+1}\right) . D^{t}\left(x^{t}, y^{t}\right)$ and $D^{t+1}\left(x^{t+1}, y^{t+1}\right) \leq 1$.

Two combined measures are used to test the impact of technology changes i.e., $D^{t}\left(x^{t+1}, y^{t+1}\right)$ and $D^{t+1}\left(x^{t}, y^{t}\right)$.

These distance functions show how high the value of the output would be if the production function in the period $t$ and $t+1$ and the value of inputs (e.g. labor and capital) in period $t$ and $t+1$ were used and vice versa. They may have a value higher than 1.

Let there be a production function for two periods $t$ and $t+1$, then calculation of the Malmquist DEA index requires two measures for a single period (model $\mathrm{M} 1$ ) and the two combined measures (model M2). A measure for a single period is calculated as the CCR DEA efficiency score for the DMUk in the observed period $t$ and $t+1$ (Charnes et al., 1978).

Let $x_{i j}^{t}$ be i-th input and $y_{r j}^{t}$ be r-th output of DMU ${ }_{j}$ in period $t$ and let $x_{i j}^{t+1}$ be i-th input and $y_{r j}^{t+1} \mathrm{r}$-th output of $\mathrm{DMU}_{j}$ in period $t+1$.

Model M1. Assume that $D^{t}\left(x_{k}^{t}, y_{k}^{t}\right)=\min Z_{k}^{t}$, with conditions

$$
\begin{aligned}
& \sum_{j=1}^{n} \lambda_{j} x_{i j}^{t} \leq Z_{k}^{t} x_{i k}^{t}, i=1,2, \ldots, m, \lambda_{j} \geq 0, j=1,2, \ldots, n \\
& \sum_{j=1}^{n} \lambda_{j} y_{r j}^{t} \geq y_{r k}^{t}, r=1,2, \ldots, s
\end{aligned}
$$

The efficiency index determines the value for which a DMU input can be proportionally reduced as the output remains the same.

In the same way the input and output data for the period $t+1$ instead of $t$ for $\mathrm{DMU}_{k}$ need to be taken to obtain a measure $D_{k}^{t+1}\left(x_{k}^{t+1}, y_{k}^{t+1}\right)=Z_{k}^{(t+1) E}$, i.e. ,

$D^{t+1}\left(x_{k}^{t+1}, y_{k}^{t+1}\right)=\min Z_{k}^{t+1}$, with conditions

$$
\begin{aligned}
& \sum_{j=1}^{n} \lambda_{j} x_{i j}^{t+1} \leq Z_{k}^{t+1} x_{i k}^{t+1}, i=1,2, \ldots, m, \lambda_{j} \geq 0, j=1,2, \ldots, n \\
& \sum_{j=1}^{n} \lambda_{j} y_{r j}^{t+1} \geq y_{r k}^{t+1}, r=1,2, \ldots, s
\end{aligned}
$$

The solution to equations (1) and (2) provides the input - oriented DEA measures of technical efficiency in periods $t$ and $t+1$, respectively. These are known as CCR (Charnes et al., 1978) models as they assume a constant return to scale (The Constant Returns to Scale Model - CRS).

Now, we need to combine periods $t$ and $t+1$. Let $t+1$ be the initial period for each $\mathrm{DMU}_{k}, k=1,2, \ldots, n$.

For the two combined measures, the optimal solution is obtained from the following linear model:

Model M2. Assume that $D^{t}\left(x_{k}^{t+1}, y_{k}^{t+1}\right)=\min Z$, where $t+1$ is initial model for each $\mathrm{DMU}_{j}$ i.e., $x^{t+1}$ is compared with the limit of period $t$ and $t+1$, with conditions 


$$
\begin{aligned}
& \sum_{j=1}^{n} \lambda_{j} x_{i j}^{t} \leq Z x_{i k}^{t+1}, i=1,2, \ldots, m, \lambda_{j} \geq 0, j=1,2, \ldots, n \\
& \sum_{j=1}^{n} \lambda_{j} y_{r j}^{t} \geq y_{r k}^{t+1}, r=1,2, \ldots, s
\end{aligned}
$$

From the above model the first combined distance measure is obtained $D^{t}\left(x_{k}^{t+1}, y_{k}^{t+1}\right)$.

Reversably, a combination of periods $t$ and $t+1$ should be taken to obtain a measure $D^{t+1}\left(x_{k}^{t}, y_{k}^{t}\right)$ where $t$ presents an initial period for each DMUj, that is

$D^{t+1}\left(x_{k}^{t}, y_{k}^{t}\right)=\min Z$, with conditions

$$
\begin{aligned}
& \sum_{j=1}^{n} \lambda_{j} x_{i j}^{t+1} \leq Z x_{i k}^{t}, i=1,2, \ldots, m, \lambda_{j} \geq 0, j=1,2, \ldots, n \\
& \sum_{j=1}^{n} \lambda_{j} y_{r j}^{t+1} \geq y_{r k}^{t}, r=1,2, \ldots, s
\end{aligned}
$$

These two combined distance measures $D^{t}\left(x_{k}^{t+1}, y_{k}^{t+1}\right)$ and $D^{t+1}\left(x_{k}^{t}, y_{k}^{t}\right)$ can take any value.

Solution models M1 and M2 (input-oriented) are the CCR score for calculating Malmquist productivity indices. Now that all four measures of distance are known, the Malmquist index ( $\left.M_{k}\right)$ of productivity can be calculated that represents their geometric mean and measures the change of input and output performances between periods $t$ and $t+1$ for the observed DMUk.

Fare R., Gtosskop S., Norris M. (1994a, 1994b) gave a definition of the Malmquist index between periods $t$ and $t+1$ in the following way:

$$
M_{k}=\sqrt{\frac{D^{t+1}\left(x^{t+1}, y^{t+1}\right)}{D^{t+1}\left(x^{t}, y^{t}\right)} \cdot \frac{D^{t}\left(x^{t+1}, y^{t+1}\right)}{D^{t}\left(x^{t}, y^{t}\right)}}
$$

The definition of Malmquist index resembles a well-known Fisher's ideal index with a combination of weights of the base and current period (see more - Marković, 2010).

The Malmquist productivity index between periods $t$ and $t+1$ can be written as the product of two components, as follows (Färe et al., 1992, 1994b):

$M_{k}=E_{k} T_{k}$,

where $E_{k}=\frac{D^{t+1}\left(x^{t+1}, y^{t+1}\right)}{D^{t}\left(x^{t}, y^{t}\right)}$ and $T_{k}=\sqrt{\frac{D^{t}\left(x^{t+1}, y^{t+1}\right)}{D^{t+1}\left(x^{t+1}, y^{t+1}\right)} \cdot \frac{D^{t}\left(x^{t}, y^{t}\right)}{D^{t+1}\left(x^{t}, y^{t}\right)}}$

The technical efficiency change index $-E_{k}$ discoses whwther bank is getting closer to the construction frontier per time. The technology change index - $T_{k}$ shows if the construction frontier is moving outwards per time. The $E_{k}$ measures changes in relative technical efficiency of the periods $t$ and $t+1$ (technical efficiency - catch up), as $T_{k}$ measures technological efficiency from the period $t$ toward $t+1$ (changes in the frontier technology - innovation). 
The values of either of these components of greater than 1 suggest an increase, while the values of less than 1 suggest the opposite.

Malmquist DEA productivity indices are used to determinate the changes in the performance of banks, industries and so on.

\section{Results and discussion}

From model M1 only summary report for banking sector is shown :

\begin{tabular}{|l|r|r|r|r|}
\hline CRS efficiency & \multicolumn{1}{|c|}{$\mathbf{1 0 0 7}$} & $\mathbf{2 0 0 8}$ & \multicolumn{1}{c|}{$\mathbf{2 0 0 9}$} & $\mathbf{2 0 1 0}$ \\
\hline geom.mean & $66,62 \%$ & $66,88 \%$ & $66,69 \%$ & $66,54 \%$ \\
\hline mean & $70,31 \%$ & $72,55 \%$ & $72,06 \%$ & $71,61 \%$ \\
\hline min. & $4,80 \%$ & $8,17 \%$ & $8,02 \%$ & $12,12 \%$ \\
\hline max. & $100,00 \%$ & $100,00 \%$ & $100,00 \%$ & $100,00 \%$ \\
\hline stan.dev. & 0,21 & 0,22 & 0,22 & 0,22 \\
\hline coef.var. & $30 \%$ & $30 \%$ & $31 \%$ & $31 \%$ \\
\hline
\end{tabular}

The average efficiency per year is about the same as the variability of efficiency. Based on these data, it can be said that the average efficiency of the banking sector in Serbia does not substantively change from year to year.

The table below shows the Malmquist indices which are obtained as a product of the Technical efficiency change between the two time periods and the Frontier shift (the change in technology between the two time periods) using formulas (6) given above.

Table 2. Malmquist indices of Serbian banks for the period 2007 to 2010.

\begin{tabular}{|c|c|c|c|c|c|c|c|c|c|}
\hline & Technical & Frontier & Malmquist & Technical & Frontier & Malmquist & Technical & Frontier & Malmquist \\
\hline \multirow[t]{3}{*}{ Banks } & efficiency & shift & index & efficiency & shift & index & efficiency & shift & index \\
\hline & change & & & change & & & change & & \\
\hline & & \multicolumn{2}{|c|}{$2008 / / 2007$} & & \multicolumn{2}{|c|}{$2009 / / 2008$} & \multicolumn{3}{|c|}{$2010 / / 2009$} \\
\hline Banca Intesa & $100 \%$ & $112 \%$ & $112 \%$ & $100 \%$ & $103 \%$ & $103 \%$ & $100 \%$ & $101 \%$ & $101 \%$ \\
\hline Komercijalna banka & $72 \%$ & $129 \%$ & $93 \%$ & $118 \%$ & $105 \%$ & $123 \%$ & $85 \%$ & $101 \%$ & $86 \%$ \\
\hline EFG Eurobank & $107 \%$ & $118 \%$ & $126 \%$ & $101 \%$ & $97 \%$ & $98 \%$ & $96 \%$ & $91 \%$ & $87 \%$ \\
\hline Raiffeisenbank & $98 \%$ & $119 \%$ & $117 \%$ & $90 \%$ & $91 \%$ & $82 \%$ & $108 \%$ & $89 \%$ & $96 \%$ \\
\hline UniCredit bank & $90 \%$ & $117 \%$ & $105 \%$ & $108 \%$ & $90 \%$ & $97 \%$ & $111 \%$ & $95 \%$ & $106 \%$ \\
\hline Hypo-Alpe-Adria bank & $95 \%$ & $106 \%$ & $101 \%$ & $84 \%$ & $98 \%$ & $82 \%$ & $113 \%$ & $94 \%$ & $106 \%$ \\
\hline AIK banka & $100 \%$ & $114 \%$ & $114 \%$ & $100 \%$ & $86 \%$ & $86 \%$ & $100 \%$ & $88 \%$ & $88 \%$ \\
\hline Societe Generale & $117 \%$ & $120 \%$ & $141 \%$ & $103 \%$ & $100 \%$ & $103 \%$ & $88 \%$ & $97 \%$ & $85 \%$ \\
\hline Alpha bank & $112 \%$ & $112 \%$ & $126 \%$ & $74 \%$ & $107 \%$ & $79 \%$ & $127 \%$ & $105 \%$ & $134 \%$ \\
\hline Vojvođanska banka & $56 \%$ & $137 \%$ & $77 \%$ & $89 \%$ & $103 \%$ & $91 \%$ & $99 \%$ & $97 \%$ & $96 \%$ \\
\hline Volks banka & $104 \%$ & $111 \%$ & $116 \%$ & $99 \%$ & $99 \%$ & $98 \%$ & $109 \%$ & $94 \%$ & $103 \%$ \\
\hline Agrobanka & $109 \%$ & $119 \%$ & $131 \%$ & $116 \%$ & $93 \%$ & $108 \%$ & $113 \%$ & $90 \%$ & $101 \%$ \\
\hline ProCredit bank & $87 \%$ & $96 \%$ & $83 \%$ & $91 \%$ & $108 \%$ & $98 \%$ & $110 \%$ & $96 \%$ & $106 \%$ \\
\hline Erste bank & $141 \%$ & $114 \%$ & $161 \%$ & $99 \%$ & $105 \%$ & $105 \%$ & $95 \%$ & $95 \%$ & $90 \%$ \\
\hline Piraeus bank & $96 \%$ & $118 \%$ & $113 \%$ & $98 \%$ & $96 \%$ & $94 \%$ & $101 \%$ & $93 \%$ & $93 \%$ \\
\hline NLB banka & $118 \%$ & $108 \%$ & $127 \%$ & $100 \%$ & $114 \%$ & $114 \%$ & $83 \%$ & $105 \%$ & $87 \%$ \\
\hline Credit Agricole bank & $114 \%$ & $107 \%$ & $121 \%$ & $102 \%$ & $112 \%$ & $115 \%$ & $99 \%$ & $100 \%$ & $99 \%$ \\
\hline OTP banka & $79 \%$ & $138 \%$ & $109 \%$ & $90 \%$ & $91 \%$ & $82 \%$ & $103 \%$ & $97 \%$ & $100 \%$ \\
\hline RB Vojvodine & $98 \%$ & $120 \%$ & $117 \%$ & $63 \%$ & $100 \%$ & $63 \%$ & $176 \%$ & $95 \%$ & $166 \%$ \\
\hline Univerzal banka & $109 \%$ & $124 \%$ & $136 \%$ & $100 \%$ & $100 \%$ & $100 \%$ & $100 \%$ & $95 \%$ & $95 \%$ \\
\hline Poštanska štedionica & $100 \%$ & $78 \%$ & $78 \%$ & $100 \%$ & $88 \%$ & $88 \%$ & $100 \%$ & $97 \%$ & $97 \%$ \\
\hline PB Beograd & $121 \%$ & $117 \%$ & $142 \%$ & $135 \%$ & $117 \%$ & $158 \%$ & $100 \%$ & $124 \%$ & $124 \%$ \\
\hline KBC banka 10 & $87 \%$ & $112 \%$ & $97 \%$ & $105 \%$ & $103 \%$ & $108 \%$ & $102 \%$ & $101 \%$ & $103 \%$ \\
\hline Čačanska banka & $105 \%$ & $126 \%$ & $132 \%$ & $94 \%$ & $108 \%$ & $102 \%$ & $95 \%$ & $100 \%$ & $96 \%$ \\
\hline Marfin bank & $88 \%$ & $112 \%$ & $99 \%$ & $76 \%$ & $108 \%$ & $82 \%$ & $123 \%$ & $94 \%$ & $116 \%$ \\
\hline Findomestic bank & $125 \%$ & $112 \%$ & $139 \%$ & $116 \%$ & $109 \%$ & $127 \%$ & $95 \%$ & $94 \%$ & $90 \%$ \\
\hline Srpska banka & $111 \%$ & $117 \%$ & $130 \%$ & $89 \%$ & $102 \%$ & $90 \%$ & $140 \%$ & $97 \%$ & $136 \%$ \\
\hline Credy banka & $188 \%$ & $77 \%$ & $145 \%$ & $115 \%$ & $108 \%$ & $124 \%$ & $48 \%$ & $90 \%$ & $43 \%$ \\
\hline JUBMES banka & $100 \%$ & $184 \%$ & $184 \%$ & $76 \%$ & $45 \%$ & $34 \%$ & $95 \%$ & $84 \%$ & $80 \%$ \\
\hline Jugobanka Jugbanka & $170 \%$ & $106 \%$ & $181 \%$ & $98 \%$ & $111 \%$ & $109 \%$ & $151 \%$ & $109 \%$ & $164 \%$ \\
\hline Opportunity banka & $112 \%$ & $116 \%$ & $130 \%$ & $121 \%$ & $103 \%$ & $125 \%$ & $89 \%$ & $97 \%$ & $87 \%$ \\
\hline Dunav banka & $112 \%$ & $134 \%$ & $150 \%$ & $99 \%$ & $90 \%$ & $88 \%$ & $33 \%$ & $112 \%$ & $37 \%$ \\
\hline Moskovska banka & & & & $218 \%$ & $92 \%$ & $201 \%$ & $120 \%$ & $93 \%$ & $112 \%$ \\
\hline
\end{tabular}


The Banca Intesa had the Malmquist index $M_{k}>100$ for the entire referent period, which means that the productivity has increased, i.e., it has a positive change in the multifactor productivity, while the Poštanska štedionica had the Malmquist index $M_{k}<100$ which means a decreased productivity, i.e., it has a negative change in the multifactor productivity. For both of the banks efficiency was $100 \%$ so it can be concluded that the frontier shift affected the value of the Malmquist index. The AlK bank which also had a $100 \%$ efficiency recorded a decrease in productivity due to a shift of limit.

Table 3. Layout of banks by Malmquist index values

\begin{tabular}{|l|r|r|r|}
\hline Malk.index & $\mathbf{2 0 0 8} / \mathbf{2 0 0 7}$ & $\mathbf{2 0 0 9 / 2 0 0 8}$ & $\mathbf{2 0 1 0 / 2 0 0 9}$ \\
\hline above 100 and 100 & 27 & 16 & 15 \\
\hline below 100 & 6 & 17 & 18 \\
\hline total & 33 & 33 & 33 \\
\hline
\end{tabular}

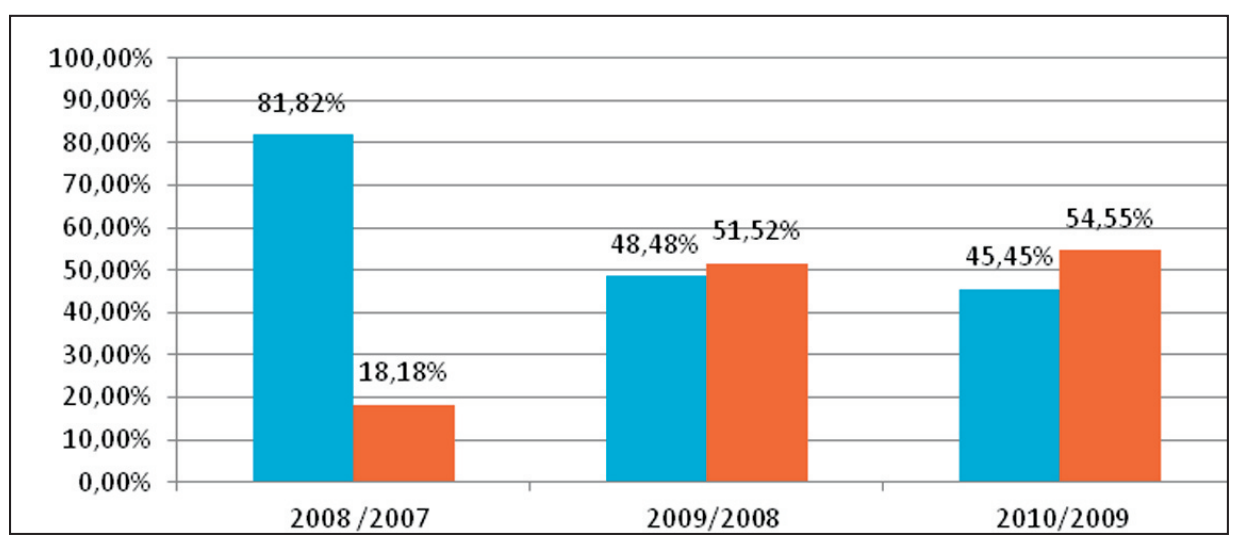

Figure 1. Layout of banks by Malmquist index values in \%, above 100 and below 100

The number of banks with Malmquist indices - $M_{k}<100$ has increased from periods $t$ and $t+1$, which means that the productivity has decreased, i.e., the negative change in multifactor productivity has increased from period $t$ and $t+1$ period; while the number of banks with $M_{k}>100$ decreases from period $t$ to period $t+1$

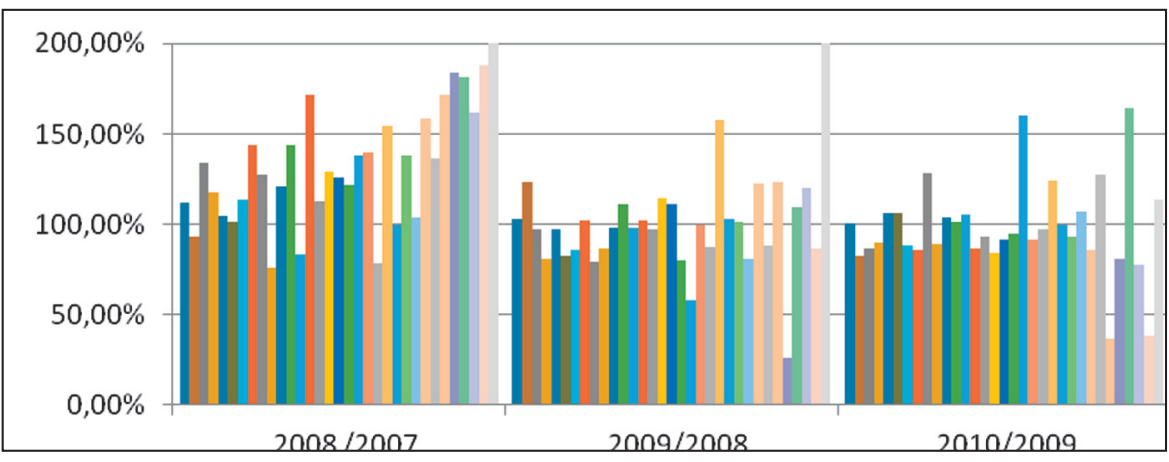

Figure 2. Malmquist index in \% for the referent periods

The table below shows geometric mean changes in technical efficiency, technology and the Malmquist productivity index from period $t$ to period $t+1$. 
Table 4. Geometric mean changes in technical efficiency, technology and Malmquist productivity index for the banking sector

\begin{tabular}{|c|c|c|c|}
\hline & Technical & Technology & Malmquist \\
\hline & efficiency & change & productivity \\
\hline & change & inde $x$ & change \\
\hline $2008 / / 2007$ & $104,42 \%$ & $115,31 \%$ & $120,41 \%$ \\
\hline $2009 / / 2008$ & $99,71 \%$ & $98,34 \%$ & $98,05 \%$ \\
\hline $2010 / / 2009$ & $99,78 \%$ & $97,03 \%$ & $96,81 \%$ \\
\hline
\end{tabular}

This table shows that the productivity fall in the banking sector is due to the reduction of technology rather than technical efficiency for the observed period. The technology change index reduces the Malmquist productivity index. A relatively large productivity increase occurred in 2008/2007.

The decrease in technical efficiency and technological efficiency must initiate strategies to improve both components and thereby the productivity of the banking sector.

Concluding remarks

This paper has aimed to present the modern scientific methods for testing the efficiency and the productivity of bank operations. In the real ambience for the DEA method application and calculation of the Malmquist productivity index, one should choose the inputs and outputs that are of great importance for the examination of banking operations. In practice, all inputs and outputs do not have the same importance. Assets, the number of employees and equity are essential elements as inputs of each bank. Revenue and EBT as outputs also have their primary weight. For an output one could take something else, such as profit before tax and after tax. In the foreign literature one can come across various input and output models for the banking sector. However, it should be noted that new scientific methods should be used as a supplement to traditional financial report analysis using known indicators of efficiency.

The expressed power of indicators of profitability, productivity and performance of banks is increasing with comparing the indicators of a concrete bank with:

- achievements of the observed bank in a successive period;

- realized indicators of competitive banks;

- target values of indicators established by the management team of the bank in defining strategic orientation.

Today, with the existence of a large number of computer software for the analysis of financial statements, it is possible to implement a number of scientific methods that can verify the classic research methodology concerning the efficiency and the productivity of banks, as well as many other companies in all branches of economic society.

\section{REFERENCES}

[1] Afsharian M., Ahn. H. ( 2015), The overall Malmquist index: a new approach for measuring productivity changes over time, Ann Oper Res, 226:1-27, DOI 10.1007/s10479-014-1668-5

[2] Andries M. A. (2011). The Determinants of Bank Efficiency and Productivity Growth in the Central and Eastern European Banking Systems, Eastern European Economics, 49(6):38-59, DOI 0.2753/EEE00128775490603

[3] Banker, R. D., Charnes, A., Cooper, W.W. (1984), "Some models for estimating technical and scale inefficiencies in data evelopment analysis", http://dx.doi.org/10.1287/mnsc.30.9.1078

[4] Bassem S. B. (2014). Total factor productivity change of MENA microfinance institutions: A Malmquist productivity index approach, Economic Modelling, 39:182-189, DOI: 10.1016/j.econmod.2014.02.035

[5] Charnes, A., Cooper, W.W., Rhodes, E. (1978), Measuring the efficiency of decision making units, European Journal of Operations Research, 2(6):429-444. DOI: 10.1016/0377-2217(78)90138-8

[6] Färe, R, Grosskopf, S., Norris, M., Zhang, Z. (1994b), Productivity growth, technical progress and efficiency change in industrialized countries, American Economic Review 84(1):66-83.

URL: http://www.jstor.org/stable/2117971 
[7] Färe, R. (1988), Fundamentals of Production Theory, Berlin: Springer-Verlag. ISBN: 978-3-540-500308, DOI 10.1007/978-3-642-51722-8

[8] Färe, R., Grosskopf, S., Lindgren, B., Roos, P. (1992), Productivity changes in Swedish pharmacies 1980-1989: a non-parametric Malmquist approach, Journal of productivity Analysis, 3(1/2):85-101, DOI 10.1007/978-94-017-1923-0 6

[9] Färe, R., Grosskopf, S., Norris, M., Zhang, Z. (1994a), Productivity Growth, Technical Progress, and Efficiency Change in Industrialized Countries", American Economic Review, 84(1):66-83. URL: http://www.jstor.org/stable/2117971

[10] Farrell, M. (1957), The measurement of productive efficiency, Journal of the Royal Statistical Society Series, 120:253-281, http://dx.doi.org/10.2307/2343100

[11] Kao C., Liu S-T. (2014). Measuring performance improvement of Taiwanese commercial banks under uncertainty, European Journal of Operational Research, 235(3):755-764. DOI: 10.1016/j.ejor.2013.11.006

[12] Knežević, P. S., Barjaktarović Rakočević, S., Durić D. (2011), Primena i ograničenja racio analize finansijskih izveštaja u poslovnom odlučivanju, (Implementation and Restraints of Financial Reports Analysis in Business Decision Making), Management - časopis Fakulteta organizacionih nauka u Beogradu, 61:25-31. UDK: 005.51:336.71

[13] Knežević, S. Marković, M., Barjaktarović Rakočević, S. (2012), Assessing efficiency in banking, Industrija - časopis Ekonomskog instituta u Beogradu, 4(3):71-92. UDK: 005.336.1:336.71

[14] Liu S-T. (2010). Measuring and categorizing technical efficiency and productivity change of commercial banks in Taiwan, Expert Systems with Applications, 37:2783-2789, DOI: 10.1016/j.eswa.2009.09.013

[15] Malmquist, S. (1953), Index Number and Indifference Surfaces, Trabajos de Estatistica, 4(2):209-242, DOI: $10.1007 / \mathrm{BF} 03006863$

[16] Marković, M. (2010), Statistika - metode i primena (Statistics - Methods and Applications), Beograd: Beogradska poslovna škola).

[17] Shephard, R. W. (1970), Theory of Cost and Production Functions (Princeton: Princeton University Press), ISBN 0-691-04198-9

[18] Shyu J., Chiang T. (2012), Measuring the true managerial efficiency of bank branches in Taiwan: A three-stage DEA analysis, Expert Systems with Applications, 39:11494-11502, DOI:10.1016/j.eswa.2012.04.005

[19] Sufian F., Habibullah S. M. (2014). Banks' total factor productivity growth in a developing economy: does globalisation matter? Journal of International Development J. Int. Dev. 26:821-852 (wileyonlinelibrary.com), DOI: 10.1002/jid.2897

[20] Yang, Z., (2009), Bank Branch Operating Efficiency: A DEA Approach, Proceedings of the International Multiconference of Engineers and Computer Scientists, Vol II, IMECS, Hong Kong, ISBN: 978-98817012-7-5

[21] Zhang J., Qu B., Xu Z., Wang P. (2012). Market development and bank profit efficiency in China: application of the generalized Malmquist productivity index, Asia-Pacific Journal of Accounting \& Economics, 19(2):181-197. DOI:10.1080/16081625.2012.667380

Receieved: July 2015. Accepted: September 2015. 


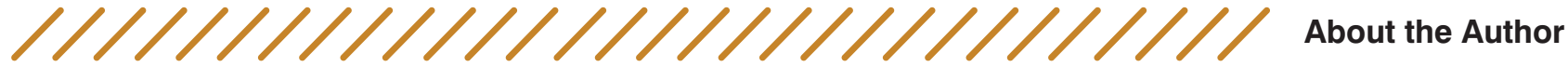

\section{Milanka Marković \\ Belgrade Business School, Belgrade}

Dr. Milanka T. Stojanovic, married Markovic was a professor at the Belgrade Business School and lectured on the subjects of Business Mathematics and Business Statistics. She graduated in 1971 in mathematics from the Faculty of Science, University of Belgrade, where she became a holder of a Masters Degree in 1975 in mathematical sciences. She defended the doctoral thesis at the Faculty of Economics in Belgrade and acquired the degree of Ph.D. in statistics. She was head of the Department of Mathematics and Statistics.

She is the author of the textbook titled Statistical Quality Control and co-author of the

Quality management textbook. Additionally, she is a co-author of the textbook titled

Business statistics (2004), of A Collection of assessment tasks from business statistics (2003), Practicum in Mathematics (2006). In addition, she has published several scientific papers in the field of mathematics and statistics. She was a designer of numerous statistical surveys. Research areas: application of mathematical methods, financial methods, as well

as statistical methods using computer software. Presently, she is a retired professor.

Snežana Knežević University of Belgrade, Faculty of Organizational Science, Serbia knezevic.snezana@fon.bg.ac.rs

Snežana Knežević was born in 1966 in Pančevo (Jabuka), where she graduated from the school of economics. She graduated from the Faculty of Economics in Belgrade where she also got her MSc degree. She got her PhD degree at the Faculty of Organizational Sciences in Belgrade. The areas of her scientific interest are Finance, Accounting and Environmental protection. She is fluent in French and English. She has published several monographs and papers of scientific and professional orientation in the country and abroad. Currently, she works at the Faculty of Organizational Sciences in Belgrade, Department of Financial Management. She is an associate member of the Scientific Society Of Economists and a member ot the EUMMAS (European Marketing and Management Association).

\section{Andrijana Brown \\ Liberty Tax Inc., Leesburg, Virginia, USA}

Andrijana Brown was born in 1976. She completed her undergraduate studies at the

Faculty of Economics in Belgrade in 2005 (Bachelors Degree in Economics, Major:

Accounting, Banking, Finance and Insurance). At Stratford University, Virginia, she completed her Masters of Science in Accounting studies. The major professional areas of her consideration are accounting, auditing and taxation issues.She is working as an Auditor in Defense Contract Audit Agency. She is a CPA candidate in Virginia.

\section{Veljko Dmitrović \\ University of Belgrade, Faculty of Organizational Sciences, Serbia dmitrovicv@fon.bg.ac.rs}

Veljko Dmitrović works at the Faculty of Organizational Sciences, University of Belgrade, at the Department of Financial Management and Accounting. He is completing his PhD studies at the Faculty of Organizational Sciences. He achieved his MSc degree in Financial Management at the Faculty of Organizational Sciences, University of Belgrade, and his BSc and MA degrees in Marketing Management at the Faculty of Economics in Subotica, University of Novi Sad. So far he has authored and coauthored more than 50 papers published in international and national journals and conferences. He has been involved in several research projects. Before the academic career he gained practical experience working for five years in "Fidelinka" a.d., Subotica.
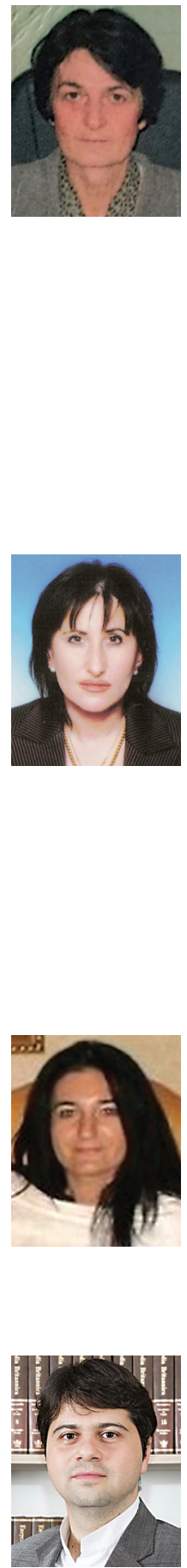